\title{
Leveraging Technology-Mediated Adult and Distance Learning for Economic Growth in Africa\#
}

\author{
Akpovire Oduaran*
}

\begin{abstract}
School for Professional Studies in Education/COMBER Research Niche Area, Faculty of Education, North-West University, Mafikeng, 2735, South Africa
\end{abstract}

\begin{abstract}
Following the rudiments of contextual analysis, and based on theoretical and philosophical analyses, this paper explores how technology mediated adult and distance learning might contribute to the economic growth of Africa, all things remaining equal. It proceeds from the perspective of analysing the related contextual situations of selected countries in Africa through the brief review of Africa's technology readiness, and posited that the possible gains that could be made from the application of adult and distance learning are tacitly located in somewhat perfect management of systems and sub-systems in education and the economy. Based on this analysis, it was proposed that whatever might be the state of Internet and technology readiness Africa has achieved, the successful creation of the nexus for economic growth is circumscribed unless the continent's political stability is assured now and in the future.
\end{abstract}

Keywords: Adult learning, distance learning, economic growth, Internet readiness, leveraging, systems, technology.

\section{INTRODUCTION}

The concept of leveraging derives from its noun form "leverage". Leveraging implies using a small amount of initial investment, credit, or even borrowed money to gain a significantly high returns in relation to an initial investment in the attempts made by an entity to control much larger investment with an intention to make appropriate gains whilst striving to reduce any liability that accrues from any loss. Leveraging technology-mediated adult and distance learning for economic growth in Africa therefore targets maximising public and private investments in the non-formal education sector by way of creating effective access to learning by more adult learners who are presumed to be the immediate contributors to economic growth in Africa.

At the macro level, various scholars have attempted to investigate the causality between education and economic growth in developed and developing countries. The findings emerging therefrom have been revealing. The results emerging from empirical studies have been mixed, to a very large extent. Most of the studies, according Phouphet Kyophilavong, Keiichi Ogawa, Byoungki Kim, Khamlusa Nouansavanh (2018), have reported that there is Granger causality running from education to economic growth. For that

*Address correspondence to this author at the School for Professional Studies in Education/COMBER Research Niche Area, Faculty of Education, NorthWest University, Mafikeng, 2735, South Africa; Tel: + 27-18-3892208;

Fax: +27 -18-3892038; E-mail: Akpovire.Oduaran@nwu.ac.za

\#Being an adapted version of a paper presented at the Annual Conference American Association for Adult and Continuing Education (AAACE), held at the Marriot Hotel, Myrtle Beach, South Carolina, USA, October 1-5, 2018. matter, the studies by De Meulemeester and Rochat (1995), for example, found that there is unidirectional Granger causality running from higher education enrolment to economic growth in Sweden, the UK, Japan, and France (Kyophilavong, Ogawa, Kim, Nouansavanh, 2018). The study by Narayan and Smyth (2004) found unidirectional Granger causality running from human capital to economic growth in China, and that by Grabowski (2003) has reported a causality running from primary, secondary, and tertiary education to growth in Japan. Afzal, Butt, Rehman, \& Begum (2009) and Afzal, Rehman, Farooq \& Sarwar (2011) have reported that there is causality running from human development to growth in Pakistan

In this same vein, some scholars have strongly proposed that human capital development that has been properly planned and implemented should surely provoke economic growth. Thus, Chuang (2000) has reported that human capital development has clearly provoked or supported economic growth in Taiwan. This proposition has been further supported by the studies carried out by Ljungber and Nilsson (2009) in Sweden; Asteriou and Agiomirgianakis (2001) and Tsamadias and Prontzas (2012) in Greece.

In contrast, Kyophilavong, Ogawa, Kim, Nouansavanh (2018) have reported that some scholars are of the view that the relationship between education and economic growth is weak Bils and Klenow (2000). One study by Self and Grabowski (2004) in India has actually reported that causality runs from the primary education enrolment to growth; but that secondary education enrolment in tertiary education does not 
Granger cause growth. That was the same thing reported by Benhabib and Spiegel (1994) with respect to Greece. Interestingly, some scholars have also argued that there is no causality running from education to economic growth in some instance. De Meulemeester and Rochat (1995) have reported that neutrality exists between higher education enrolment and economic growth in Australia just as Levine and Renelt (1992) have reported that in Italy education does not significantly impact growth. It must be noted that these mixed empirical results depend on the variables applied in each case, and the country specifics. This also means that we cannot just simply rationalize that what is applicable in say India or Laos is also applicable in say Kenya or Botswana or Ghana or Nigeria. It all depends on the variables being manipulated in each study and context. Be that as it may, one can confidently propose that the fact there exist causality between education and economic growth should tacitly apply to technology-mediated adult and distance learning planning and implementation in the context selected for discussion in this paper.

Much as the literature reports causality between education and economic growth, in the context of Africa, there seems to be a gap on how technologymediated adult and distance learning can perform the same function. Empirical studies in this direction cannot be safely conducted until the theoretical background has been laid, and this is the major goal this paper is aimed at achieving.

The paper proceeds from exploring a set of basic assumptions, goes through the analysis of related contextual situations of selected African countries, a brief review of the continent's technology readiness, application of technology mediated adult and distance learning to economic growth, possible challenges and, based on this procedure, provides some recommendations. It posited that the possible gains that could be made from the application of technologymediated adult and distance learning are tacitly located in somewhat perfect management of systems and subsystems in education and the economy.

\section{BASIC ASSUMPTIONS}

The approach implied in this discourse had always been there, but the gains might have been minimal. The first assumption here, therefore, is that technologymediated adult and distance learning needs to be extensively deconstructed and then reconstructed such that it could become a more visible and effective widespread contributor to economic growth in Africa.

For all intents and purposes, the digital economy is fuelled by speed, scale and competition. If that is the case, it becomes necessary to firstly attempt to assess technology-mediated adult and distance learning direct contribution to Africa economic growth by exploring the existing gaps in knowledge which ought to be filled for good results to be realized.

A discourse of this nature is constrained by the fact that Africa is a continent that is made up of more than 53 countries, islands and archipelagos. Thus, it is surely unrealistic for anyone to want to paint on a large canvass such as this continent of Africa. And this is why the main purpose of this paper can only be achieved by selecting a few countries to illustrate the arguments and propositions being made here. If this purpose is achieved, one would have contributed effectively to the pool of knowledge that is being developed to accelerate economic growth in Africa.

Harvesting the potentials of technology-mediated adult and distance learning to effect the economic growth that Africa needs is based on some specific assumptions. Firstly, the major goal of economic growth we are aiming at can never happen unless there is a gauged and sustained and well monitored and evaluated investment in massive infrastructural turnaround strategy in technology systems. Yet, most African nation's economies are struggling to survive in the midst of bad governance.

Overcoming the perpetual bad governance that seemed to have plagued the continent requires real courage, openness, and corporate and international cooperation. As things are, one would venture to say that very few African nations will have or ever have the internal capacity and courage to overturn bad governance without any risk of lives. And this threat real threat to the lives of those who can ever venture to voice out their opposition to bad governance has remained a hydra-headed problem for decades as one autocratic leader after the other presides over the economic decay of one nation or the other for a long time now. If therefore, the challenge of bad governance is reversed and the "right" leaders are elected based on fair practice to run the affairs of African nations, there would be hope that proper national investment in and management of technology or digital systems can be guaranteed for the elements of good governance to 
find space to emerge and get applied for the benefit of most Africans.

Securing the large-scale investment in infrastructure should open the way to the pursuit of effective delivery of real time, pervasive data intelligence gathering, data evaluation and data security management. Data security management would be badly needed to ensure that the system is not compromised such that the gains Africa expects to make in applying technologymediated adult and distance learning to economic growth do not become ephemeral.

Effectively transforming adult and distance learning in Africa from its largely traditional analogic systems is a daunting task that can only be supported by a readiness to allow it have the trained and committed expertise to drive the process. Technology would have to be made part and parcel of literacy and numeracy programs as it has occurred in Kenya, the post-literacy programs in South Africa and open and distance learning at the tertiary level in Botswana, Ghana, Kenya, Nigeria and South Africa.

Another major assumption would have to be the transformation of how adult learners live and work using the power of data garnered from technology. Fortunately, smart phones are becoming readily available and at relatively low costs in many African nations. For example, adults in Kenya can now do some form of commercial transactions using their smart phones. That experience is also already happening in Ghana, Nigeria, Rwanda and South Africa. Even when electricity supply from the major public sources gets problematic, solar-energy propelled smart-phone and lap-tops are gradually emerging as national initiatives in Kenya. To that extent, unreliable power supplies will eventually be obviated, more or less.

And the gains in economic growth in Africa should be based on such other assumptions as:

The more you know about the economy as adult, the better your entire nation and in terms of the ability of its citizens to participate profitably in consumption and financial investments.

The more adult learners acquire digital knowledge and skills, the more effectively they can scale up the volume of data that comes through on their internet and other digital devices.

The more the quality of data adults have, the more they will be able to focus on collection, connection, storage and retrieval of data to keep making informed economic decisions.

$>$ Digitalised adult and distance learning capacitation of adult learners may lead ostensibly to their ability to gather and analyse data across platforms, infrastructure and clouds such that they can determine what should matter most to them as far as their knowledge of investment is concerned and real-time economic engagements in agriculture, commerce, literacy, post-literacy, open and distance learning, community education and lifelong learning, all things being equal.

Automation is increasingly driving all areas of life and artificial intelligence and machine learning should sooner than later become the sine-quanon for business scaling capacity to compete effectively. This may accelerate economic forecast and timely delivery which can be harnessed for growth.

And all things being equal, only scaled continuous investment, experimentation and uncertainty management made possible by pervasive data intelligence across the economic spheres of the African nations should stand the test of time. This is why Africa must embrace and implement large-scale application of technology to adult and distance learning as a sure way of enhancing its economic growth.

If these assumptions are closely linked to stable and trusted political stability, Africa should be well on the way to the vivid economic growth that has largely been limping for a long time now.

\section{THE CONTEXTS}

Africa is, perhaps, the third largest continent in the world. It has 53 independent states, 46 of which are situated on the continent itself, six are islands and archipelagos constituting states and (Equatorial Guinea) includes a continental territory and islands (Les editions J.A. 2002:24-55). Africa is at the cusp of economic growth, but the slow pace with which it is catching up with other continents must be the result of multiple factors. However, it is impossible for one single discourse to account for all these factors, and at the same time seek to provide solutions. In fact, no single intervention alone will proffer ideas that should accelerate Africa's economic growth. It is, therefore, expedient for one to purposively select one approach, 
being the technology-mediated adult and distance learning, that can effectively enhance most immediately the rate at which Africa gains access to, and participate in, the global digital economy that has become the new norm for a long, long time now.

The Mwalimu, Julius Nyerere, founding president of the Republic of Tanzania, once proposed that the economic production of today lies squarely on the shoulders of adult persons even as we invest in the future of Africa's children. It is the adult population in any nation that plans and implements the macro and micro economic systems and resources. It is this same adult population that maps out and implement the social and political structure today. Knowing this, anyone who undermines this critical mass in national development planning cannot be doing anything valuable, and there is grave risk that can result from neglecting them.

No pretence is being made in this discourse to the effect that technology-mediated adult and distance learning alone can be the bulwark of Africa's economic growth. Far from that kind of expectation, one should rather quickly propose that achieving the goal of economic growth in the continent would require a great deal of sustained investment in building partnerships, determination, and innovative approaches.

\section{BRIEF ASSESSMENT OF AFRICA'S TECHNOLOGY READINESS}

Africa is reported to be holding just 10.0 per cent of the global Internet take. If that is the case, does really stand a chance of effectively applying technology towards the enrichment of its adult and distance learning programs such that they can enhance economic growth? This question had been partly dealt with by other scholars who were much more interested in the general aspects of the application of technology to commerce, health, agriculture and general education, but to a lesser degree when it comes to adult and distance learning for some unspecified reasons. In fact, the study reported by Lancaster (2016) that covered Algeria, Angola, Benin, Botswana, Burkina Faso, Burundi, Cameroon, Chad, Cote d'Ivoire, Democratic Republic of Congo, Djibouti, Egypt, Eritrea, Ethiopia, Gabon, Gambia, Ghana, Guinea, Kenya, Lesotho, Liberia, Libya, Madagascar, Malawi, Mali, Mauritius, Morocco, Mozambique, Namibia, Nigeria, Rwanda, Senegal, Sierra Leone, South Africa, South Sudan, Sudan, Swaziland, Tanzania, Tunisia, Uganda, Zambia and Zimbabwe has indicated that within Africa, there is considerable diversity in the availability and capability of mobile telecom infrastructure. What seems to make Africa particularly peculiar is that the vast tracks of lands in the continent are very sparsely populated, and this is especially so in the northern desert regions where network coverage remains thin.

However, intense investment programs that have been piloted by several pan-regional operators in recent years have seemingly enhanced the population coverage in many African nations. Studies on the Internet take in Africa have revealed something quite interesting. For example, Lancaster (2016) has reported that much of the phenomenal growth in the take-up of mobile voice and data services might have come from the lack of fixed-line alternatives in many African countries. What this means is that the prevalence of lack in Africa's fixed-line availability has worked surprisingly in the positive direct opposite, and the rural areas that were previously neglected in the distribution of the common public social infrastructures have been spared Africans the agony of frequently being left behind in the overall development agenda of many countries.

Africa's telecommunications market liberalization efforts started some two decades ago have begun to work out for good for more and more people as the largely government-owned telecommunication enterprises that had held the monopoly of provision have been made to compete for investment patronage in the open market. Therefore, the predominant little commercial incentive to invest in infrastructure combined with a lack of regulatory oversight, poor management and government neglect, and fixed-line penetration that had remained very low by global standards are being ostensibly turned around for good to the advantage of most Africans in a way, especially in such war-ravaged countries like the Central African Republic, Democratic Republic of the Congo, Somalia, Sudan, South Sudan and Libya where the paltry infrastructures that had been put in place stood the risk of being damaged or knocked down by skirmishes.

In many African countries, mobile voice and data services are filling in the previously experienced technology utilization gap pretty effectively (Dutta \& Bilbao-Osoria, 2012). As a result, in many African countries the use of telecoms services might just as well be changing from being predominantly mobile to becoming mainly mobile, and this should be to the advantage of adult and distance learning in the continent. 
With the side-lining of investment in fixed-line infrastructure in favour of mobile infrastructure, especially in spectrum which utilizes $700 \mathrm{MHz}$ band, the analogue system is sure to become a thing of the past in Africa. Service providers are also reportedly strengthening the effectiveness and spread of their networks by way of migrating from $3 G$ to LTE-based services. It is anticipated that when this development is further supported by increased international connectivity from a number of new submarine and terrestrial cables, Africa, in general, might well be on the way to joining the other better furnished continents in the world in terms of applying the Internet and social media usage to socio-economic and political development. Projects aimed at bringing this anticipated goal into fruition reportedly include the SACS cable running between Angola and Brazil, with onwards connectivity to Miami, as well as the Liquid Sea cable being built by the pan-regional infrastructure provider Liquid Telecom along the continent's east coast (Lancaster, 2016).

Most probably, the surest support for enhancing adult and distance learning programs in Africa will come from the provision and use of affordable smartphones which are in very high demand right now in many countries. Smartphones, in fact, have become the primary mobile device used among rural and urban dwellers in Africa.

For instance, Nigeria achieved a milestone in the telecommunication industry in 2007 with the launching of the first African Communication Satellite, NigComSat 1. The State Accelerated Broadband Initiative (SABI) and the National Rural Telephony Programme (NRTP) were also among the various government efforts to make information and communication technology available to Nigerians in this period (Iwuagwu, 2015). In fact, government planned to use NigComSat 1 to create jobs, save foreign exchange, provide Internet Access especially to the remote areas of the country and encourage tele-education, which was specifically designed to facilitate distance learning (Bubou, 2010: 35 - 49). This was followed in May 2009, by the auctioning of spectrum slots in the $2.3 \mathrm{GHZ}$ band, which were won by two Companies SPECTRANET and MOBITEL (Ndukwe, 2011).

It is important to note that prior to the launch of mobile services in August 2001, the ownership of telephones in Nigeria had remained the exclusive privilege of the rich and well-to-do as well as the wellconnected individuals in the society (Iwuagwu, 2015).
However, within the first ten years of its introduction, as the Table 3 below shows, the environment had drastically changed. In fact, the country's telecommunication sector recorded phenomenal growth both in terms of subscriber base and infrastructural development. Similarly, telephone ownership had been completely democratized. By September 2011, the active subscriber base was 93.5 million and $66.7 \%$ teledensity. This growth was made possible by the injection of about US $\$ 18$ billion of private investment in license fees, infrastructure development, building local capacity, empowering local companies that provide support services etc. In addition, most of the countries highways were covered by mobile signals; several rural communities now had access to one form of telecommunication service or the other; the country's law enforcement community had the necessary tools to keep in touch with their bases; even as small, medium and large businesses had been empowered by these vital ICT tools (Ndukwe, 2011). The reform in Nigeria is still ongoing, but there is still a lot of work to be done, especially given the size of its population.

In terms of StatsSA's General Household Survey ("GHS") nationally a high number of households in South Africa had access to some form of a telecommunication service in 2015 , with only $3.5 \%$ (compared to $4.1 \%$ in 2014 ) not having any access to either a landline or a cellular phone (ICASA, 2017). By way of comparison, in $201585.5 \%$ (83.1\% in 2014) of households had access to at least one (1) cellular phone, $10.9 \%$ (decreased from $12.6 \%$ in 2014) had access to both a landline and a cellular phone service and only $0,1 \%$ had access only to a landline service (ICASA, 2017). Just over half of South Africa's households $(53.5 \%)$ had at least one member who used the Internet either at home, workplace, place of study, or Internet café in 2015. For Gauteng the figure was $65.7 \%$ and the Western Cape $63.3 \%$, whilst just over one-third $(39.3 \%)$ of household in Limpopo had access to the Internet.

Now, the challenge of affordability has been partly met by the offer of cheaper units manufactured locally on the continent. It is now common knowledge that the growing take-up of such devices has been supporting the tremendous growth in m-commerce, m-money and $\mathrm{m}$-banking services in the continent; and, therefore, their extension to the offer of adult and distance learning will pose little or no problems as such. The only limitation might be the relative availability and mobility of knowledgeable and skilled personnel to 
safeguard and service regularly the infrastructures, especially as the dearth of public electricity supply remains one bane of development in Africa.

Lancaster (2016) has made the point that more than three quarters of mobile phone subscribers in Africa are expected to subscribe to broadband services by 2020 , compared to about a fifth that used that same device in early 2016, and that with more than a billion mobile subscribers in the region this presents a vast market for vendors and application providers. It is acknowledged that the relatively low purchasing power in the region may not translate into a similarly rapid growth in revenue, considerable potential remains.

The general picture of technology presence and usage in Africa is provided in Tables 1 and $\mathbf{2}$ below:

From Table 1 below, we observe that whilst the Global Internet Penetration stood at 61.7 per cent as at June $30^{\text {th }}, 2017$, the African continent figure was 31.2 per cent during the same period. Although this data might look worrisome when compared with what might be taking place in continents such as Asia and Latin America, the fact that Africa has made such a remarkable catch-up, so to say, when it comes to Internet Penetration should mean for the continent the assurance that getting every African to be properly served is a goal that can be achieved if the necessary infrastructures and motivation for learners in adult and distance learning programs are put in place.

This same reflection was observed in the data reported for the 2017 Internet Users in Africa. Table 2 below reveals the situation as follows:
From Table 2 below, it would seem that the baseline Internet Usage data for 2017 are a remarkable improvement on the data for the year ending in December, 2000. That improvement might have come from come from the relative improvement in investments in hardware purchases not just by the public but also be the private sectors of the different African nations.

The data released in Table 2 below by the Miniwatts Marketing Group as at June 2017 revealed that African countries, islands and archipelagos with $50 \%$ Internet penetration against the $55.8 \%$ recorded for the rest of the world as of 2017 included Kenya (89.4\%), Mauritius (62.7\%), Morocco (58.3\%), Saint Helena (50.4\%), Senegal 956.5\%), South Africa (54.0\%) and Tunisia $(50.9 \%)$. It might well be that these African countries should be able to apply with relative ease the internet to the design and delivery of adult and distance learning program and services to citizens who would be interested especially in lifelong learning engagements that are not necessarily credential-based.

On the other hand, African countries and Islands that recorded $40 \%$ plus but not up to $50 \%$ internet penetration as a percentage of the overall population as at June 2017 included Algeria (45.2\%), Cape Verde (48.2\%), Gabon (48.1\%), Libya (43.7\%), Mayotte (FR) $(42.7 \%)$, Nigeria (47.7\%), Reunion (FR) (44.7\%), Uganda (45.6\%) and Zimbabwe (41.1\%).

In addition to the two categories of countries and Islands depicted above in terms of internet penetration is a third category whose average was equal to or exceeded the overall African average of $31.2 \%$.

Table 1: Internet Penetration in Africa as at June, 2017

\section{Internet Penetration in Africa June 30, 2017}

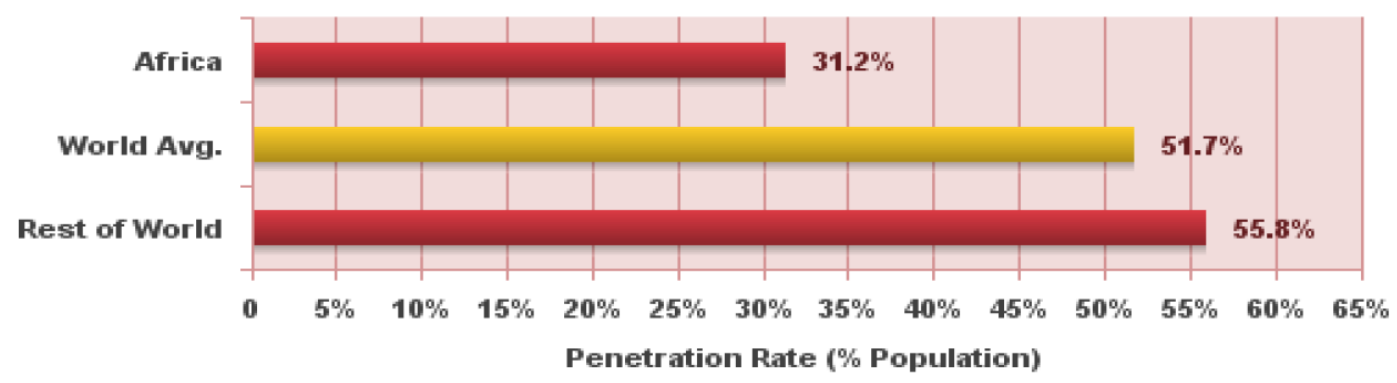

Source: Internet World Stats - www.internetworldstats.com/stats $1 . \mathrm{htm}$

$388,376,491$ estimated Internet users in Africa in June 30, 2017 and

$3,885,567,619$ Internet users in all the World in June 30, 2017

Copyright @2017, Miniwatts Marketing Group 
Table 2: Internet Users Statistics for Africa (Africa Internet Usage, 2017 Population Stats and Facebook Subscribers)

\begin{tabular}{|c|c|c|c|c|c|c|}
\hline \multicolumn{7}{|c|}{ AFRICA 2017 POPULATION AND INTERNET USERS STATISTICS FOR 2017} \\
\hline Algeria & $41,063,753$ & 50,000 & $18,580,000$ & $45.2 \%$ & $37,060.0 \%$ & $18,000,000$ \\
\hline Botswana & $2,343,981$ & 15,000 & 923,528 & $39.4 \%$ & $6,056.9 \%$ & 690,000 \\
\hline Burkina Faso & $19,173,322$ & 10,000 & $2,684,265$ & $14.0 \%$ & $26,742.7 \%$ & 600,000 \\
\hline Burundi & $11,936,481$ & 3,000 & 617,116 & $5.2 \%$ & $20,470.5 \%$ & 450,000 \\
\hline$\frac{\text { Central African }}{\underline{\text { Rep. }}}$ & $5,098,826$ & 1,500 & 246,432 & $4.8 \%$ & $16,328.8 \%$ & 66,000 \\
\hline Chad & $14,965,482$ & 1,000 & 748,274 & $5.0 \%$ & $74,727.4 \%$ & 170,000 \\
\hline$\underline{\text { Comoros }}$ & 825,920 & 1,500 & 65,578 & $7.9 \%$ & $4,271.9 \%$ & 60,000 \\
\hline$\underline{\text { Congo }}$ & $4,866,243$ & 500 & 400,000 & $8.2 \%$ & $79,900.0 \%$ & 400,000 \\
\hline Congo, Dem. Rep. & $82,242,685$ & 500 & $5,107,271$ & $6.2 \%$ & $1,021,354.2 \%$ & $2,100,000$ \\
\hline$\underline{\text { Cote d'Ivoire }}$ & $23,815,886$ & 40,000 & $6,318,355$ & $26.5 \%$ & $15,695.9 \%$ & $2,400,000$ \\
\hline Ethiopia & $104,344,901$ & 10,000 & $16,037,811$ & $15.4 \%$ & $160,278.1 \%$ & $4,500,000$ \\
\hline Gabon & $1,801,232$ & 15,000 & 865,492 & $48.1 \%$ & $5,669.9 \%$ & 470,000 \\
\hline Gambia & $2,120,418$ & 4,000 & 392,277 & $18.5 \%$ & $9,706.9 \%$ & 220,000 \\
\hline Ghana & $28,656,723$ & 30,000 & $9,935,286$ & $34.7 \%$ & $33,017.6 \%$ & $4,000,000$ \\
\hline Guinea & $13,290,659$ & 8,000 & $1,302,485$ & $9.8 \%$ & $16,181.1 \%$ & 950,000 \\
\hline Guinea-Bissau & $1,932,871$ & 1,500 & 84,000 & $4.3 \%$ & $5,500.0 \%$ & 84,000 \\
\hline Kenya & $48,466,928$ & 200,000 & $43,329,434$ & $89.4 \%$ & $21,564.7 \%$ & $6,200,000$ \\
\hline Lesotho & $2,185,159$ & 4,000 & 597,860 & $27.4 \%$ & $14,846.5 \%$ & 290,000 \\
\hline Liberia & $4,730,437$ & 500 & 395,063 & $8.4 \%$ & $78,912.6 \%$ & 330,000 \\
\hline Libya & $6,408,742$ & 10,000 & $2,800,000$ & $43.7 \%$ & $27,900.0 \%$ & $2,800,000$ \\
\hline Madagascar & $25,612,972$ & 30,000 & $1,300,000$ & $5.1 \%$ & $4,233.3 \%$ & $1,300,000$ \\
\hline Malawi & $18,298,679$ & 15,000 & $1,758,503$ & $9.6 \%$ & $11,623.4 \%$ & 720,000 \\
\hline Mali & $18,689,966$ & 18,800 & $2,212,450$ & $11.8 \%$ & $11,668.4 \%$ & $1,000,000$ \\
\hline
\end{tabular}


(Table 2). Continued.

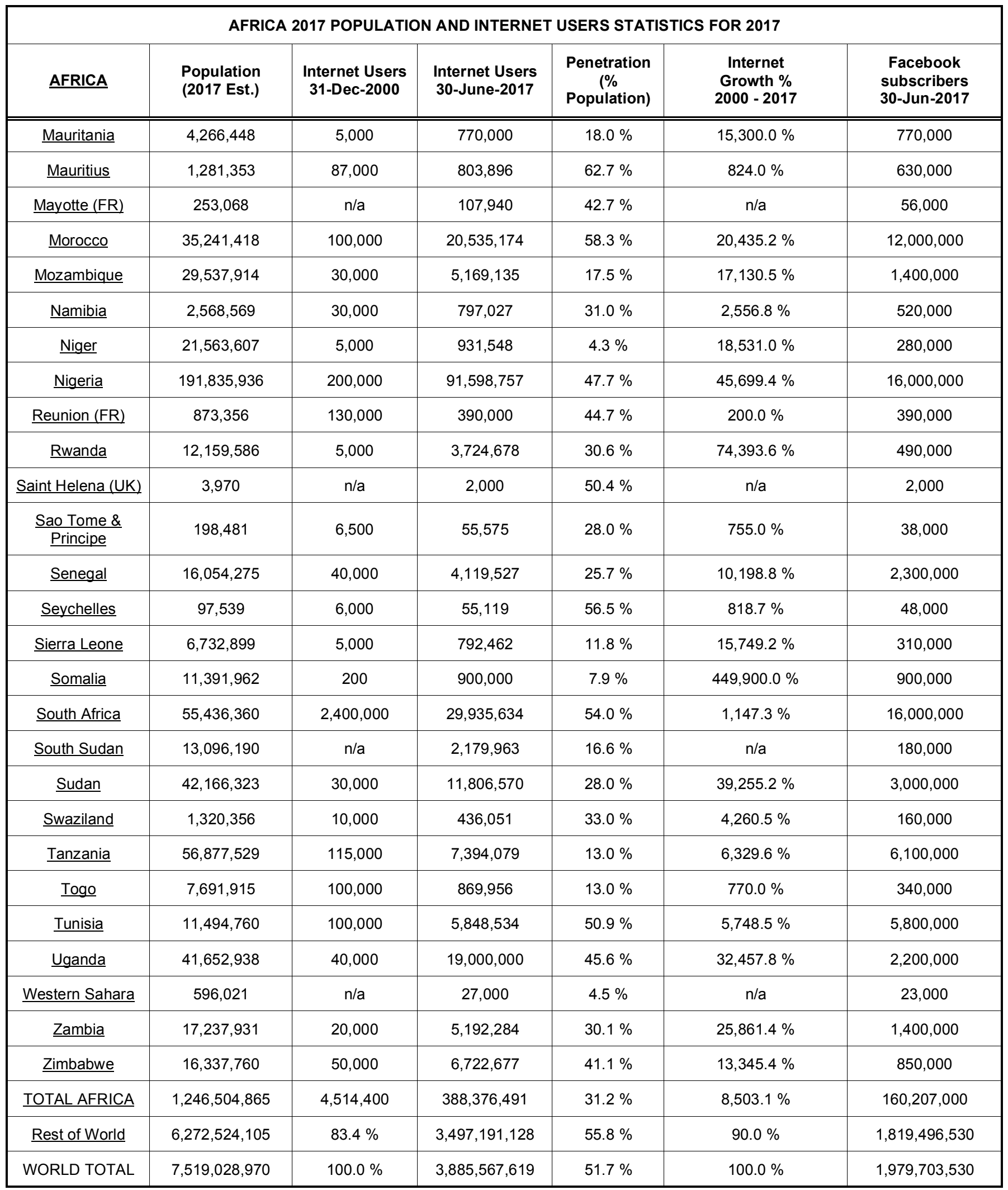

NOTES: (1) Africa Internet Statistics were updated in June 30, 2017. (2) Africa Facebook subscribers are in June 30, 2017. (3) CLICK on each country name for further data on individual countries and regions. (4) Africa Population numbers are mid-year 2017 estimates, based on data from the United Nations Population Division. (5) For definitions, navigation help and methodology, see the site surfing guide. (6) Africa Internet usage information comes from, among others, data published by WWW, ITU, Facebook, and other trustworthy sources. (7) For Internet growth comparison purposes, baseline Internet usage data for the year 2000 is also displayed. (8) Data from this table may be cited, giving the due credit and establishing a link back to internetworldstats.com Copyright 2017, () Miniwatts Marketing Group. All rights reserved worldwide. 
Included in this third category are Botswana (39.4\%), Egypt (39.2\%), Ghana (34.7\%) and Swaziland (33.0\%).

So then, overall, it could be said that there are twenty-one countries and islands or archipelagos in Africa where the prospects for applying technology to adult and distance learning programs delivery almost look bright. Twenty-one out of the total fifty-eight African countries and islands or archipelagos with internet penetration should give anyone some hope for success in terms of applying technology to improve the quality of life for millions of Africa and, much more contextually, the enrichment of adult and distance learning programs delivery and participation on the African continent.

Nevertheless, on a closer observation, it is possible that there are still a whole lot of African countries and Islands or archipelagos where the prospects for widespread application of technology remain circumspect. For example, there are still African countries with less than 10 per cent internet penetration against the percentage of their overall population; and, to this last category belong Burundi $(5.2 \%)$, the Central African Republic 94.8\%), Chad (5.0\%), Comoros (7.9\%), Congo (8.2\%), Democratic Republic of Congo $(6.2 \%)$, Eretria $(1.3 \%)$, Guinea $(9.8 \%)$, Guinea-Bissau $(4.3 \%)$, Liberia $(8.4 \%)$, Madagascar $(5.1 \%)$, Malawi (9.6\%), Niger (4.3\%) and Somalia (7.9\%).

What these data released by the Miniwatts Marketing Group (2017) do indicate is that it will be difficult to generalize for Africa the response to the application of technology to the effective delivery of adult and distance learning programs. This difficulty is compounded by the fact that the data did not even indicate how much of the internet penetration actually applies to adult and distance learning programme delivery and its distribution measured against the level of adult literacy achievements, Gross Domestic product, National Income Brackets and the culpable factor of gender. This is a grey area for research that should inform investment in broadband and collaboration between specific African countries and islands or archipelagos. This collaboration may be at the levels of governments, institutions of adult and continuing education, agencies or organisations and the private sector. Unfortunately, it would seem as if the private investor may be much more driven by profitability of investments over and above other considerations. This may be rightly so, but the pursuit of the overall development of the African continent may be held down for a very long time if profit alone remain the dominant factor in human development and relationship

\section{APPLICATION TO ECONOMIC GROWTH}

It might be quite superfluous for one to imagine that technology can have exactly the same application and effects across the several African nations for reasons already pointed out earlier in this paper. However, there are common areas in which technology can have immediate value and application, and it is possible to outline just a few of them in this discourse.

The way and manner African adult and distance learning has been conceptualised, designed and implemented seems to be reflecting largely the vestiges of its colonial past. Firstly, the intentions that were behind the goals of adult and distance learning were tightly linked to meeting the immediate needs of the colonisers. So, therefore, one would observe that the Asquith and Elliot Commissions that were initiated to meet the learning needs of adults in Nigeria, for example, were firstly liberal than anything else. Clerks, interpreters of official government communication on how people should comport themselves and/or meet the needs of the colonial enterprise were to be educated or trained through the machinery of colonial type of adult education. It was good and valuable at that time for one to be literate and numerate to be deemed useful to the colonial administration whether in the British or French or Portuguese colonies. When eventually many African nations became politically independent, the vestiges of the colonial past were retained. This was true of Ghana as it was true of Kenya, Nigeria, and Uganda. For a very long time and up till now, in some cases, the pursuit of adult literacy, and distance learning which has given way to open and distance learning, remained the pivots of adult learning in most African countries. Sooner than later, political independence meant that African governments should design and implement economic systems that should make their nations become able to compete in the knowledge and digital economy. Globalisation came along with its reliance on technology; and African governments and leaders soon discovered how unprepared they were to compete favourably in the emerging economic systems. That also, meant that even the formal education systems could not really and effectively meet the needs of the new global economy. 
This reality was made even more visible by government failures as some African nations were embroiled in seemingly endless political crisis. Sometimes, wars and insurgencies, for example in the Niger Delta of Nigeria and lately the North-Eastern Nigeria, just as it has been in Somalia, South Sudan and Libya became really challenging. Liberia, SierraLeone, Cote de Voire, Mozambique and Rwanda had their own fair share of internal conflagration all of which made real reforms in education almost impossible.

As other constraints began to make advancements in the application of technology to economic growth, African nations have come to realize how far they have been left behind. Fortunately, many of the African nations have begun to introduce technology into their different services, including adult and distance learning.

The adult and distance learning systems in many African nations have begun to be deconstructed in order to give way to the badly needed reconstruction processes that have the application of technology as the launching pad for making programs attractive and valuable contributors to better life and economic growth. It is critical at this point to attempt a discussion of the areas technology-mediated adult and distance learning might help in promoting economic growth in some African countries.

\section{Maternal Education}

Maternal education is very closely tied to African children's prospects for survival at the point of birth. It has been proposed that if the average child mortality rate for Africa were to fall to the level of children born to women with some kind of secondary education, Africa, in particular, may record 1.8 million fewer deaths, indeed a 41 per cent reduction had been anticipated (UNESCO, 2011). And maternal education that covers vaccinations, oral rehydration therapy, nutrition and the identification and treatment of epidemics and diseases using technology, especially among young mothers with a minimum level of education is one of the urgently needed assistance.

\section{Technology and HIV-Positive Mothers}

If technology can quickly reach child-bearing age mothers who are HIV and AIDS positive with information on how to prevent mother-to-child transmission by using anti-retroviral treatment during pregnancy, or how the epidemic can easily be reduced by using condoms and deal with stigmatization, Africa would be spared the agony of battling with an epidemic that is proving to be pervasive in some way, especially because of its prevalence.

In 2016, there were 19.4 million adults and children living with HIV and AIDS, 790,000 new infections and 420,000 adult and child deaths due to AIDS in Eastern and Southern Africa as against the 6.1 million adults and children living with HIV, 370,000 adults and children newly infected and 310,000 adult and child deaths due to AIDS in the Western and Central African sub-regions that make up Sub-Saharan Africa (UNAIDS, 2017). UNAIDS (2017) has also reported that as of 2016, an estimated 16.5 million [range: 13.9 - 19.2 million] children worldwide had lost one or both parents to AIDS, and that more than 80 per cent of these children (13.8 million) live in sub-Saharan Africa. The scenario is presented in Table 3 below:

\section{Adult Literacy}

The 2000 Dakar Framework for Action envisaged that literacy opens the doors to better livelihoods, improved health and expanded opportunity if adult illiterates can be reached systematically. But in a situation where there are conflicts, populations sparsely distributed in the desert and semi-arid areas, leadership failures and poor governance, reaching adult illiterates with technology hooked on their mothertongue and through committed civil societies and NonGovernmental Organizations can be a wonderful solution to the many years of neglect.

Table 3: Global Summary of HIV Epidemic among Children (0-14 years), Eastern and Southern Africa, 2016

\begin{tabular}{|c|c|c|c|c|}
\hline \multicolumn{2}{|c|}{ Global } & \multicolumn{2}{c|}{ Eastern and Southern Africa } & Male \\
\hline Female & Male & Female & 690,000 & $67 \%$ \\
\hline \hline $1,100,000$ & $1,100,000$ & 670,000 & 40,000 & $49 \%$ \\
\hline 77,000 & 81,000 & 39,000 & 30,000 & $49 \%$ \\
\hline 57,000 & 59,000 & 29,000 & \\
\hline
\end{tabular}

Source: UNAIDS 2017 estimates.

Note: Due to rounding, values may not sum to total. 


\section{Technology and the Disruption of Patriarchy}

Technology can work increasingly fairly rapidly for the most neglected populations in Africa where patriarchy is reigning supreme. The question might be asked as to why emphasis should be placed on women and girls. In 2008, globally about 796 million adults lacked basic literacy skills and nearly two-thirds of them were women (UNESCO, 2011). That position has not changed even in 2017. Women and girls still form the bulk of adult and youth illiterates in Africa, and the application of technology in literacy programs can be an attraction if there are enough computer-literate facilitators to go round, but that remains a tall order in many of the rural communities in Africa.

\section{Child Development}

Although UNESCO (2017) has reported that the percentage of stunted children in Africa, in particular, fell from 48 per cent to 38 per cent between 1990 and 2013 especially in Malawi, Rwanda, Senegal and the United Republic of Tanzania, the application of technology is much more likely to accelerate the gains being made in this area of child development (UNESCO, 2017). Technology using the smartphones as a platform can focus substantially on paediatric nutrition will provide rapid nutrition to stunted child development.

\section{SOME CHALLENGES}

The rapid appreciation and application of technology in Africa will not be an easy walk over as many might think. There are challenges that need to be identified and addressed very quickly if the intention is to catch up with other continents. It is trite to consider some of the major challenges as follows:

\section{Armed Conflicts}

African countries like the Democratic Republic of the Congo, South Sudan, Somalia and to extent, Libya all of which are experiencing one kind of armed conflict or the other remain far from reaching the Education For All goals largely because the atmosphere that is conducive to teaching and learning and the set-up of the necessary frameworks for technology will be obviously lacking to a large extent.

Much worrisome is the reality prevailing in African countries affected by armed conflicts and those that are neck-deep in one form of insurgency or the other; for example, Nigeria, Niger, Mali and the Central African
Republic, to mention but a few that are most likely to divert scarce public funds from education into military spending (UNESCO, 2011).

\section{School Dropout and Adult Illiteracy}

It has been reported that in Africa alone, 10 million children drop out of primary school every year (UNESCO, 2011). The challenge here is that the huge number of children that drop out of primary school annually will certainly increase adult illiteracy and thus wiping out the gains already made (UNESCO, 2015). It was reported in 2015 that Africa accounted for $26 \%$ of the global number of adult illiterates, up from the $20 \%$ in 2000 .

Although UNESCO anticipated that only Burundi, Equatorial Guinea and South Africa would achieve the target of halving adult illiteracy between 2000 and 2015 , over the same period the average adult illiteracy rate dropped by less than 30 per cent but with 12 countries still remaining far from reaching that target, among them being Burkina Faso, Chad and Mozambique (UNESCO, 2017).

\section{Funding}

Investment and superfast Internet traffic is not cheap in any way. Therefore, the challenge here would be if Africa does have the funding sources and financing patterns that can really support the innovative application of technology to adult and distance learning on the scale that will be realistic and effective.

\section{RECOMMENDATIONS AND CONCLUSIONS}

Whatever gains Africa seeks to derive from applying technology-mediated adult and distance learning to economic growth would depend largely on many factors. First, there must be the guarantee that we have democratic and obviously transparent and corruption free leadership and good governance in the continent. This will be a tall order until African institutions of governance especially those that relate to free and fair elections, transparency and accountability are guaranteed.

Economic systems and sub-systems in the economy would have to be run by people who understand investment patterns, security, and the pursuit of open market systems that do not disadvantage Africans in the first place. In this regard, it might sound ridiculous, but the appointments to the management of the economic systems in Africa must 
be based on merit and commitment to the course of promoting the growth of modern and technology driven economy everywhere on the continent.

Natural resources exploration everywhere on the continent would have to be based on fair practices. This would guarantee the safety of the resources and the attraction of investors whose capitals we need very badly.

The education systems and, in particular, the nonformal education systems in Africa would have to be more generously funded and managed by people who understand how best technology can be applied at minimal costs, since many African countries are still struggling in terms of national incomes. Adult and distance learning in Africa would have to drift more rapidly towards ensuring that we have easier penetration of technology into what is existing at the moment. The personnel to plan and manage this goal would have to be provided much more easily than presently exists in many parts of Africa.

The vigorous drive towards expanding the scope of fixed infrastructure is good enough for Africa. Perhaps, there is now need to ensure that African countries that are less able to pursue the speed of Internet penetration are assisted, especially on the basis of the language blocs that are now existing in Africa.

It is hoped that if the recommendations above are implemented with careful monitoring, Africa should be in a position to ensure that its adult and distance learning programs are made attractive to reach more adults who are presently employed whilst making available to the teeming army of unemployed African youth the leverage of technology based skills development programs.

Outwardly, some of the recommendations might appear outlandish, but it is certain that if African leaders have the will, they can overcome the challenges already outlined above in this paper. If there is this will, catching up with the rest of the world in terms of economic growth should sooner than later become a reality.

\section{REFERENCES}

Africa Internet Usage (2017). Population Stats and Facebook Subscribers.

Asterious, D., \& Agiomirgianakis, G.M 2001, Human capital and economic growth: Time series evidence from Greece, Journal of Policy Modeling, 5(23): 481-489. https://doi.org/10.1016/S0161-8938(01)00054-0
Afzal, M., Butt, A., Rehman, U. H., \& Begum, I 2009, A dynamic analysis of the relationship among human development, exports and economic growth in Pakistan, The Pakistan Development review, 48, 885-920.

Afzal, M., Rehman, U. H., Farooq, S. M., \& Sarwar, K 2011, Education and economic growth in Pakistan: A cointegration and causality analysis, Internal Journal of Educational Research, 50, 321-335. https://doi.org/10.1016/j.ijer.2011.10.004

Benhabib J., \& Spiegel M. M 1994, The role of human capital in economic development: evidence from aggregate crosscountry data, Journal of Monetary Economics,34, 143-73. https://doi.org/10.1016/0304-3932(94)90047-7

Bils M., \& Klenow P.J 2000, Does schooling cause growth? American Economic Review, 90, 1160-1183. https://doi.org/10.1257/aer.90.5.1160

Bubou, G. (2010). "Platform Technologies and Socio-Economic Development: The Case of Information and Communication Technologies (ICTs) in Nigeria", International Journal of Emerging Technologies and Society, 9 (1): $35-49$.

Chuang, Y 2000, Human capital, Export, and economic growth: A causality analysis for Taiwan, 1952-1995", Review of International Economics, 8(4), 712-720. https://doi.org/10.1111/1467-9396.00252

De Meulemeester J. L., \& Rochat, D 1995, "A causality analysis of the link between higher education and economic development", Economics of Education Review, 14, 351361.

https://doi.org/10.1016/0272-7757(95)00015-C

Dutta, S. and Bilbao-Osorio, B. 2012. The global information technology report 2012. Living in a hyperconnected world. World Economic Forum.

Engle, R. F., \& Granger, C. W. J 1987, Co-Integration and error correction: representation, estimation, and testing", Econometrica, 55(2), 251-276. https://doi.org/10.2307/1913236

GoL 2011, 7th National Socio-Economic Development Plan (20112015), Ministry of Planning and Investment (MPI), Laos

Grabowski, H.G 2003, The price of innovation: new estimates of drug development costs, Journal of Health Economics, 2(22), 151-185.

Kyophilavong, P., and Toyoda, T 2012, Evaluating the Impact of Mining Foreign Capital Inflows on the Lao Economy in Kitahara, M and Czerkawski, C. (eds), Social Systems Solutions Applied by Economic Sciences and Mathematical Solutions, Kyushu University Press.

Kyophilavong, P, Ogawa, K, Kim, B \& Nouansavanh, K., (2018). Does education promote economic growth in Lao Pdr? Evidence from cointegration and Granger Causality Approaches. The Journal of Developing Areas, 52 (2), Spring: 1-11 https://doi.org/10.1353/jda.2018.0018

ICASA. 2017. $2^{\text {nd }}$ Report on the State of the ICT Sector in South Africa $31^{\text {st }}$ March 2017. https://www. ellipsis.co.za/wpcontent/uploads/2017/05/ICASA-Report-on-State-of-SA-ICTSector-2017.pdf Retrieved $24^{\text {th }}$ April, 2018 @ 1:54 p.m.

Iwuagwu, O. 2015. Telecommunication reforms in China and Nigeria: Same result, different strategies. The Journal of International Social Research. Vol. 7(32).

Les Editions, J.A. (2002). Africa Atlases: Nigeria. Paris: Les Editions J.A.

Levine, R. \& Renelt, D 1992, A Sensitivity Analysis of Cross-Country Growth Regressions, American Economic Association, 4(82), 942-963.

Ljungberg, J., \& Nilsson, A 2009, Human capital and economic growth Sweden 1870-2000, Cliometrica, 3, 71-95. https://doi.org/10.1007/s11698-008-0027-7 
Lancaster, H. (2016). Africa - Mobile Infrastructure and Mobile Broadband, https://www.budde.com.au/Research/AfricaMobile-Infrastructure-and-Mobile-Broadband/?r=51

Miniwatts Marketing Group (2017). internetworldstats.com/stats.1/htm Retrieved 12/03/2017.

Ndukwe, E. (2011), "The Telecommunication Revolution in Nigeria", Convocation Lecture delivered at Igbinedion University, Okada

https://www.iuokada.edu.ng/files/c/The\%20Telecommunicati ons \%20Revolution\%20In\%20Nigeria.pdf Retrieved $24^{\text {th }}$ April, $2018 @ 2: 11$ p.m.

Nigeria Communication Commission (NCC) (2018) https://www.ncc.gov.ng/about-ncc/mandate Assessed on $24^{\text {th }}$, April, 2018.

Narayan, P.K. \& Smyth, R 2004, Temporal Causality and the Dynamics of Exports Human Capital and Real Income in China, International Journal of Applied Economics, 1(1), 2445.

Ogawa, K 2008, Higher education in Lao People's Democratic Republic: Historical Perspective. Journal of International Cooperation Studies, 6(1), 105-129.
Self, S. \& Grabowski, R 2004, Does education at all levels cause growth? India, a case study, Economics of Education Review, 1(23), 47-55. https://doi.org/10.1016/S0272-7757(03)00045-1

Tsamadias, C., \& Prontzas, P 2011, The effect of education on economic growth in Greece over the 1960-2000 period, Education Economics, 20(5), 522-537. https://doi.org/10.1080/09645292.2011.557906

UNESCO (2011). Education for All (EFA) Global Monitoring Report 2011: The hidden crisis: Armed conflict and education. Unesco.org/images/0019/001911/191186e.pdf. Retrieved $15 / 03 / 2018$.

UNESCO (2015). EFA Global Monitoring Report 2015: Regional Overview: $\quad$ https://en.unesco.org/gem-report/sites/gemreport/files/regional_overview_SSA_en.pdf. Retrieved 24/02/2018.

UNESCSO (2017). EFA Global Monitoring Report 2015: Regional Overview: $\quad$ https://en.unesco.org/gem-report/sites/gemreport/files/regional_overview_SSA_en.pdf. Retrieved $15 / 03 / 2018$

Received on 08-11-2018

\section{DOI: https://doi.org/10.6000/1929-7092.2019.08.04}

(C) 2019 Akpovire Oduaran; Licensee Lifescience Global.

This is an open access article licensed under the terms of the Creative Commons Attribution Non-Commercial License (http://creativecommons.org/licenses/by-nc/3.0/) which permits unrestricted, non-commercial use, distribution and reproduction in any medium, provided the work is properly cited. 